ZOOLOGIA 28 (3): 305-311, June, 2011

doi: $10.1590 /$ S1984-46702011000300004

\title{
Breeding biology and reproductive success of Polystictus superciliaris (Aves: Tyrannidae), an uncommon tyrant-flycatcher endemic to the highlands of eastern Brazil
}

\author{
Diego Hoffmann ${ }^{1,2} \&$ Marcos Rodrigues ${ }^{1}$
}

\author{
${ }^{1}$ Pós-graduação em Ecologia, Conservação e Manejo de Vida Silvestre, Departamento de Zoologia, Instituto de Ciências \\ Biológicas, Universidade Federal de Minas Gerais, Caixa Postal 486, 31270-901 Belo Horizonte, MG, Brazil. \\ ${ }^{2}$ Corresponding author. E-mail: diego_hoffmann@hotmail.com
}

\begin{abstract}
Polystictus superciliaris (Wied, 1831) is a small tyrant-flycatcher endemic to mountaintops in the highlands of eastern Brazil. In this paper we present the first description of the breeding biology of $P$. superciliaris and estimate its reproductive success from a population inhabiting rocky outcrops. This study was conducted during 2005 in the Parque Estadual da Serra do Rola Moça, municipality of Nova Lima $\left(20^{\circ} 03^{\prime} \mathrm{S}, 44^{\circ} 00^{\prime} \mathrm{W}\right)$, state of Minas Gerais, southeastern Brazil. Fourteen pairs of $P$. superciliaris were banded and monitored. The onset of the breeding season in 2005 was assumed to have been sometime before the 26th of July, while it was assumed to have ended on the $23^{\text {rd }}$ of November based on the last observation of a successful brood. Clutch size was invariably two eggs $(N=21)$, the incubation period averaged $17.7 \pm 1.3$ days $(N=9)$, and the nestling period averaged $16.4 \pm 1.3$ days $(N=8)$. We estimated the probability of reproductive success for $P$. superciliaris to be $41.3 \%$, during this particular breeding season. Of the $12(57.1 \%)$ unsuccessful nests, eight (66.7\%) had eggs and four (33.3\%) had nestlings when they failed. In nine (42.8\%) of these cases, the nests were lost to predation, two to parasitism by botflies, and one due to abandonment. This study suggests that the reproductive success of $P$. superciliaris is intermediate compared to the other species of Tyrannidae that have been studied and closer to the lower limit of the $40 \%-80 \%$ range which is characteristic of tyrant - flycatcher species that breed in temperate regions.
\end{abstract}

KEY WORDS. Canga; clutch size; laying date; Mayfield method; nest predation.

The tyrant flycatchers (Aves: Tyrannidae) are a large and variable group of birds, consisting of 429 currently recognized species, mostly restricted to the Neotropics. (Fitzpatrick 2004). The nesting behavior and diet of many Tyrannid species are still completely unknown, and detailed information concerning the breeding biology and reproductive success of most species is lacking (Fitzpatrick 2004).

One of the most poorly known Tyrannid genera is Polystictus (Vieillot, 1817), which includes the relatively common and widely distributed Bearded Tachuri, Polystictus pectoralis (Vieillot, 1817), and the Gray-backed Tachuri, Polystictus superciliaris (Wied, 1831), an uncommon species with a very restricted range (FitZPATRICK 2004).

Individuals of $P$. superciliaris are small, weighing just 6 grams, and are endemic to mountaintops in the highlands of eastern Brazil. The species occurs from 900 to $1950 \mathrm{~m}$ and has a patchy distribution along the Espinhaço and Mantiqueira mountain ranges, where it inhabits rocky outcrops amidst a savanna-like habitat known as "campos rupestres", and highaltitude grasslands known as "campos de altitude" (VASCONCELOS et al. 2003, Hoffmann et al. 2007). Within this restricted range, the Gray-backed Tachuri is considered uncommon in both habitats (BIRDLIFE 2004). However, this perceived frequency of occurrence is largely anecdotal, as there are no published studies that have investigated the population size and habitat preferences of $P$. superciliaris.

Most of the geographical range of $P$. superciliaris lies within the Quadrilátero Ferrífero region of southeastern Brazil, an area known for high-quality iron ore deposits that are of worldwide economic importance (ЈАСов et al. 2007). The iron-ore mining process removes the topsoil and all of the existing vegetation. The subsequent hardening and ultimately impoverished state of the remaining substrate hampers the revegetation process, whether by natural or artificial means (Teixeira \& Lemos Filho 2002). This destructive mining practice is the most serious threat to the campos rupestres habitat in southeastern Brazil (JАСовI \& CARMO 2008, JАСові et al. 2007). The increasing rate of converting undisturbed areas for cattle ranching and urban development is also an ongoing threat to this unique habitat (StatTersfield et al. 1998, VASCONCElos 1999). In light of its distinctive flora, high degree of species endemism and significant anthropogenic pressures, the Espinhaço Range was recently 
declared an area of extreme importance for biodiversity conservation (DRUMMOND et al. 2005).

The small range and patchy distribution of the known populations of $P$. superciliaris, in combination with the high rate of conversion of the species' habitat and deficiency of data regarding its reproductive biology, qualifies this species to be considered Near Threatened by the IUCN (BIRDLIFE 2004).

Although it is an endemic species with a very restricted distribution, making it more susceptible to becoming endangered, the basic natural history of $P$. superciliaris is still poorly known and, to date, no detailed study of its breeding biology exists. In fact, the only previously available information on the breeding behavior of $P$. superciliaris is a description of a single nest and egg (VASCONCELOS \& Lombardi 1996). In this paper we present the first formal description of the breeding biology of $P$. superciliaris, and provide baseline data for egg-laying dates, nest site characteristics, egg morphology, clutch size, incubation and nestling periods, and the estimated reproductive success of a population inhabiting campos rupestres in the core area of the Quadrilátero Ferrífero region of southeastern Brazil.

\section{MATERIAL AND METHODS}

Our study was conducted during 2005 in the Parque Estadual da Serra do Rola Moça (hereafter RM), a state park in the municipality of Nova Lima $\left(20^{\circ} 03^{\prime} \mathrm{S}, 44^{\circ} 00^{\prime} \mathrm{W}\right)$, Minas Gerais, southeastern Brazil. RM is 3942. ha in size and is located in a transitional area between the Atlantic Forest and Cerrado biogeographical domains, both of which are considered to be biodiversity hotspots (MitTermeier et al. 2004).

The population of $P$. superciliaris we studied was found inhabiting an area of "canga" outcrops with shrubby vegetation at an altitude of $1500 \mathrm{~m}$. Canga is a Brazilian term used to describe a superficial hematite deposit (Jасов \& CARmo 2008). In the Quadrilátero Ferrífero, cangas are often actual ironstone rock islands located on mountaintops (JАСові et al. 2007). These outcrops are dominated by shrubby vegetation and harbor a high number of sedges, grasses, and orchids (JACOBI \& CARMO 2008). The most common plant species are the shrubs Baccharis reticularia DC. (Asteraceae), Lychnophora pinaster Mart. (Asteraceae), Tibouchina multiflora Cogn. (Melostomataceae), the orchids Acianthera teres (Lindl.) Borba (Orchidaceae) and Sophronitis caulescens (Lindl.) Van den Berg \& Chase (Orchidaceae), the grasses Andropogon ingratus Hack. (Poaceae) and Paspalum scalare Trin. (Poaceae) and the sedges Bulbostylis wimbriata Clarke (Cyperaceae) and Lagenocarpus rigidus Nees (Cyperaceae) (JАСOBI et al. 2007). The climate in this region is mesothermic, with mean annual rainfall of $1500 \mathrm{~mm}$ that is concentrated during November-March and a prolonged dry season when there is a high risk of wildfires, especially from April to October (NIMER \& BRANDÃo 1989).

Adult $P$. superciliaris were captured with mist-nets and each individual was fitted with a metal leg band provided by the
Brazilian Environmental Agency (CEMAVE-IBAMA) and marked with a unique combination of colored plastic leg bands.

Nests were located by observing adult birds carrying nest material during the nest construction period or food items during the nestling period between July and December of 2005 . The onset of egg laying and subsequent stages of the breeding cycle were determined by periodically visiting the nesting territories. After a nest was found, it was checked daily until the first egg was laid and then at three to five day intervals until fledging or nest failure occurred. We adopted this conservative nest monitoring interval as a precaution against observer-induced nest desertion or inadvertently increasing the chances of nest predation.

For each nest, on evaluation day, we recorded the number of eggs and nestlings, as well as the general daily status (construction, egg, nestling, predated, abandoned). We also measured the length and width of each egg, the internal and external diameter of each nest, as well as the external height of the nest walls, the depth of the incubation chamber, the height of each nest above ground level, and its shape.

We defined the incubation period as the time between the laying of the last egg, until the hatching of the first egg. The nestling period was defined as the time between the hatching of the first egg, until the time of fledging by the last member of the brood. We considered a nest to have been predated when its contents disappeared before the nestlings had reached a stage of development that would likely have enabled them to leave the nest on their own. Because it can be difficult to determine whether an egg predation event occurred during the egglaying or incubation period, we followed the recommendation of Robinson et al. (2000) and pooled the data from both periods. Nestlings found dead and heavily parasitized by botfly larvae (Philornis sp.) were considered to have died from the ill effects of the parasite.

The lengths of the incubation and nestling periods were estimated by assuming that any change in nest status, such as hatching, fledging or predation, occurred at the midpoint between the penultimate and ultimate nest checks (Robinson et al. 2000).

Breeding synchrony was calculated using Kempenaers index (1993). We considered the number of fertile days for female as eight days, based on the estimates of other studies (BIRKHEAD \& MølLer 1992, Rodrigues 1996). Breeding success was estimated as the percentage of successful nests and according to Mayfield's method, which considers the daily and period survival rates (DSRs and PSRs) during the egg and nestling periods (MAYFIELD 1961, 1975). Differences between DSRs and PSRs were tested using the method of HeNsler \& Nichols (1981). A nest was considered successful if it was found empty, without any signs of predation and if the young had developed enough to leave the nest (MAson 1985). We also calculated the mean annual production of each reproductive pair that was monitored as the number of individuals fledged per pair of nesting adults. 


\section{RESULTS}

We banded and monitored 14 breeding pairs of $P$. superciliaris. Although this species is sexually monomorphic, we were able to determine the respective genders of each mated pair by observing their behavior. For example, one nest was being observed at the moment when the female was laying the first egg. This banded female immediately flew off to a nearby bush and laid the egg while perched. This egg broke, but two days later, the same female returned and laid a second egg inside the nest. Incubation and nest building activities were realized entirely by this female, with no assistance from her mate.

Based on these observations, we were able to distinguish the sexes of the other mated pairs by carefully observing nest building and incubation behaviors. Furthermore, in all of our observations, only one bird performed these particular tasks, so we felt confident in assigning gender based on our assumptions.

We assumed that the onset of the 2005 breeding season took place sometime before July 26 , because eggs were already being incubated in the first nest we located. The last successful brood was completely fledged on the $23^{\text {rd }}$ of November. One pair was observed incubating after this date, but the nest was predated on the $7^{\text {th }}$ of December.

\section{Nest description}

The nest of $P$. superciliaris is tall, cup-shaped and placed in the fork of a branch within a bush (SIMON \& PACHECO 2005). Nests in our study $(\mathrm{N}=21)$ were all placed in the fork of a branch stemming directly from the trunk of a bush at a height of lower than $1 \mathrm{~m}$ (Fig. 1). Mean measurements of nests were $36.9 \pm 3.5$ $\mathrm{mm}$ for the internal diameter, $56.0 \pm 8.3 \mathrm{~mm}$ for theexternal diameter, $40.9 \pm 3.7 \mathrm{~mm}$ for the depth of the cup, and $64.7 \pm 7.6$ $\mathrm{mm}$ for the height of the external wall of the nest $(\mathrm{N}=17)$.

Nests were composed of grass and leaf fragments, flower parts of Asteraceae species and the leaves and rachises of Mimosa calodendron Mart. (Fabaceae). The fragments of vegetation used in the nest construction were fixed to the supporting branches with spider webs and silk from butterfly cocoons. The nest cups were lined with contour and down feathers. Nests were gray-brownish and resembled the overall coloration of the dominant bushy vegetation in our study area.

While the females built the nest, the males assumed mateguarding activity. During nest construction activity, the males were always observed in close proximity to their mates. However, when an observer approached a nest site, the male started singing while the female discretely flew away through the low vegetation. Nest building activity was more intense after 09:00 $\mathrm{h}$. In the beginning of the breeding season (end of July and August), females took longer to complete a nest, with an average nest construction period of 17.5 days $(\mathrm{N}=7)$. At the end of the breeding season (end of September and December), the average time required to complete a nest was 11.5 days $(\mathrm{N}=5)$. We did not observe any cases of females reusing material from an abandoned or predated nest.

\section{Egg description}

Eggs were white or light cream in color, with no streaking or spotting (Fig. 2), oval-shaped with average dimensions of 15.4 $\pm 0.5 \mathrm{~mm}$ long and $12.2 \pm 0.4 \mathrm{~mm}$ wide $(\mathrm{N}=8)$. Clutch size was invariably two eggs $(\mathrm{N}=21)$ and egg laying occurred very earlier in the morning, from July to December, with an approximately 48 hour interval between the first and second egg.
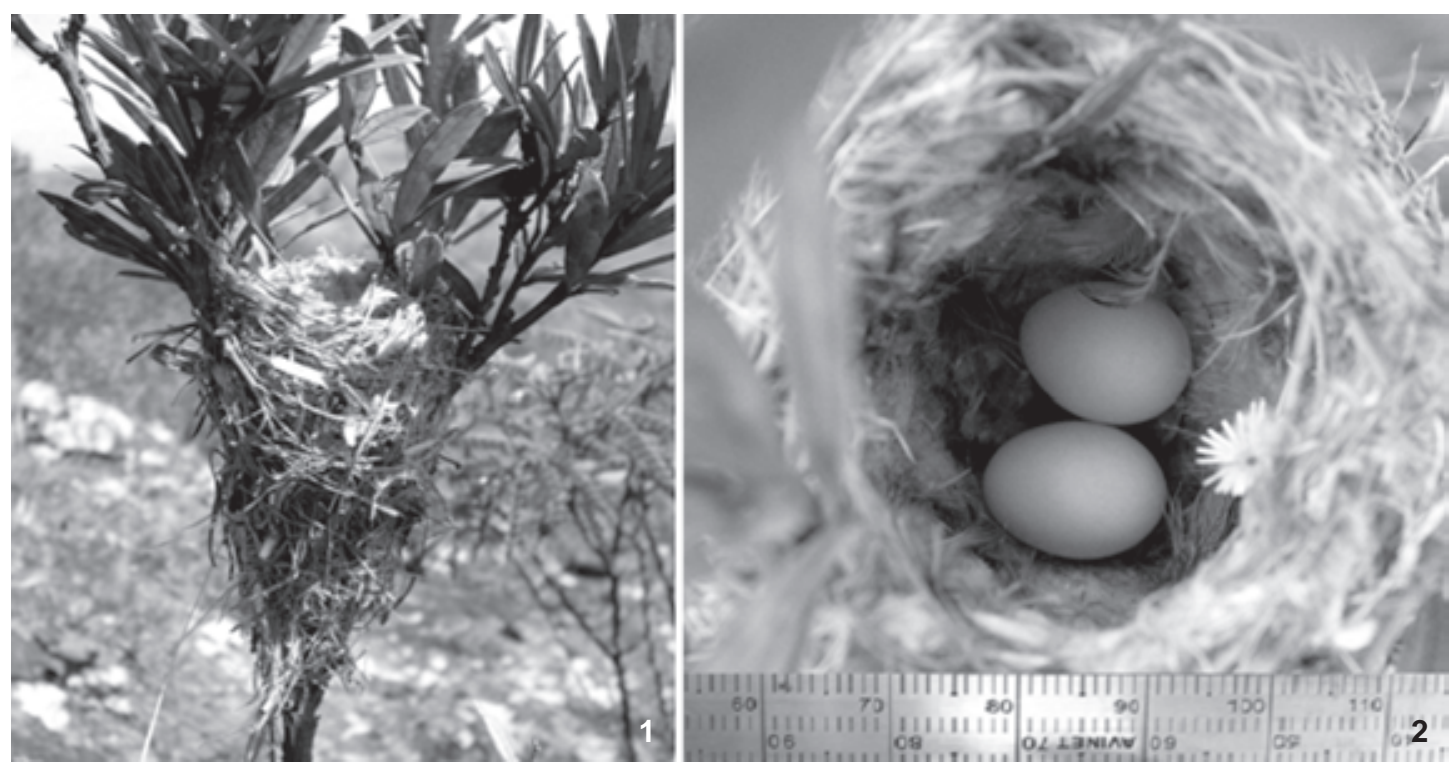

Figures 1-2. Nest (1) and eggs (2) of P. superciliaris in the Parque Estadual da Serra do Rola Moça, Minas Gerais, Brazil. Photos by D. Hoffmann. 


\section{Incubation}

Females were solely responsible for incubation efforts. We observed that females leave the nest unattended in order to forage, because males did not provision them with food during the incubation period. The incubation period averaged $17.7 \pm 1.3$ days $(\mathrm{N}=9)$.

\section{Nestlings}

Polystictus superciliaris chicks were altricial, emerging from the egg with their eyes closed and with some downy feathers on their orange colored skin. The nestlings had orange gapes with yellow flanges $(\mathrm{N}=8)$ and their eyes opened eight days after hatching $(\mathrm{N}=2)$. The nestling period averaged $16.4 \pm 1.3$ days $(\mathrm{N}=8)$. Fledglings were distinguishable from adults by their shorter tails and paler coloration on the breast and tarsi, but these distinguishing features only lasted for approximately two weeks after fledging.

\section{Parental care}

Both adults were observed feeding nestlings. We did not observe any cases of eggshell or fecal sac removal but we suspect that it does occur because we found no signs of egg shells or feces in or below any of the nests. Fledglings were provisioned for up to 34 days $(\mathrm{N}=2)$. In one instance, we observed a breeding pair accompanied by a newly fledged bird 70 days after their first brood had fledged. We did not note this supposed second breeding attempt. Fledglings appear to remain in the parental territories for about 35 to 45 days before dispersing to adjacent areas.

\section{Multiple breeding attempts}

Eight of the 13-breeding pairs made two to three nesting attempts during the monitored period. The building of a new nest after a failed attempt starts immediately. Nesting attempts, successes and failures are presented in figure 3.

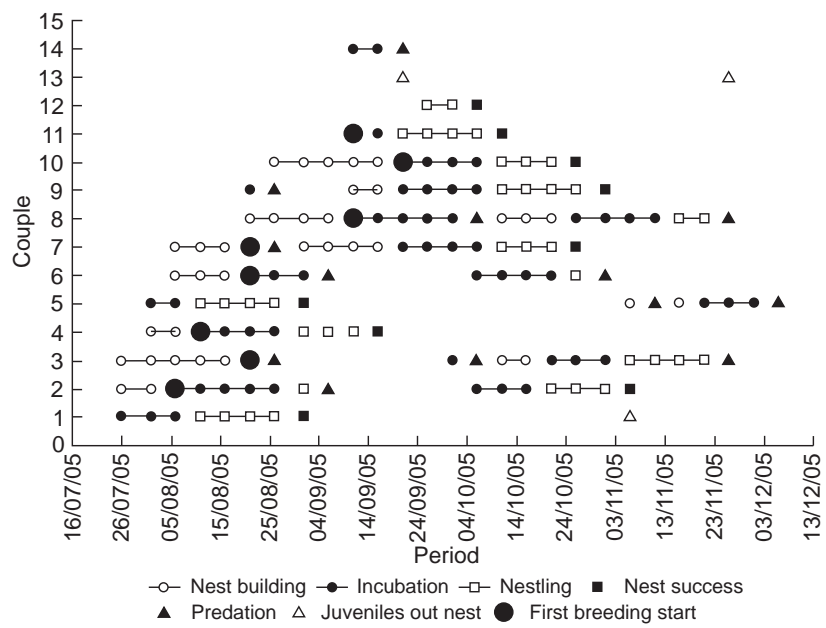

Figure 2. Reproductive stages of $P$. superciliaris in 2005 in the Parque Estadual da Serra do Rola Moça, Minas Gerais, Brazil.

\section{Breeding synchrony}

Of the 14-mated pairs of $P$. superciliaris that were monitored, we believe that the first nesting attempt was recorded for 11 of these. According to the method of estimating the breeding-synchrony index (Kempenaers 1993), we did not observe the existence of synchronized breeding (16.6\% of synchrony) among the eight mated pairs whose nests were located before the first egg was laid.

More specifically, a nest with eggs was located as early as late July, while two additional were found between August 510; five more were encountered between August 15-25 and three late nesting attempts were observed between August 26 and September 20. The reproductive season of $P$. superciliaris appears to continue into December. Our last observation of egg laying was on November 23, but this nest had failed by December 7 , due to predation (Fig. 3 ).

\section{Reproductive success}

We located and monitored 21 nests created by 13 different breeding pairs of $P$. superciliaris. Nine $(42.8 \%)$ of these nests were successful, fledging a total of 16 offspring. According to Mayfield's method, we estimated the probability of reproductive success to be $41.3 \%$. Of the 12 (57.1\%) unsuccessful nests, eight $(66.7 \%)$ contained eggs and four $(33.3 \%)$ were in the nestling stage when they failed (Tab. I). Nine of these unsuccessful nests $(42.8 \%)$ were lost to predation (seven with eggs and two with nestlings), two to parasitism by botflies, and one to abandonment. We found no difference between the daily survival rate (DSR) of nests with eggs compared to those with nestlings (97.3\% and $97.8 \%$, respectively) $(Z=0.32$ and $P=0.75)$.

Table I. Mean \pm standard deviation (SD) of the daily survival rate (DSR) and period survival rate (PSR) of $P$. superciliaris. Days-nest corresponds to the number of days a nest was active. Lost corresponds to the number of eggs and nestlings lost during the study period.

\begin{tabular}{lcccc}
\hline \multicolumn{1}{c}{ Period } & Days-nest & Lost & DSR \pm SD & PSR \pm SD \\
\hline Incubation & 306.5 & 8 & $0.973 \pm 0.009$ & $0.592 \pm 0.110$ \\
Nestling & 185.0 & 4 & $0.978 \pm 0.010$ & $0.698 \pm 0.126$ \\
\hline
\end{tabular}

The presence of parasites prior to total nest failure was observed in only one instance, while in the second case of nest failure due to parasitism, the cause of the failure was only identified after the nestlings were found dead in the nest with a large number of emergent larvae present. In all cases were a nesting attempt was considered successful, the offspring were observed together with the adults in their respective territories.

The annual productivity of $P$. superciliaris in the study area during this particular breeding season was estimated to be 1.4 fledglings per pair. One mated pair was thought to have been successful in two separate nesting attempts, producing two fledglings in the first and one fledgling in the second at- 
tempt - although the nests were not actually located and this assumption was based on observations of the marked adult birds with fledglings. Another mated pair for which we were able to monitor the first nesting attempt and band the fledglings after fly, presented another fledgling after a period of 35 days, although a second nest was never located. Including our observations of these two pairs, 14 breeding pairs and a total of 20 fledglings were recorded in the study area.

\section{DISCUSSION}

The nests and eggs of $P$. superciliaris located in our study were very similar to those described previously (VASCONCELOS \& LOMBARDI 1996). Egg-coloration and markings are quite variable within this exceptionally large group of birds and there are other tyrant-flycatcher species that construct open nests and also have clear eggs (Lopes \& MARINI 2005a).

The onset of the breeding season for $P$. superciliaris is somewhat earlier than that of the majority of passerine species breeding in southeastern Brazil that been studied thus far, which is typically from September to November (MarINI \& DURães 2001). Even on a local scale, it seems that most birds inhabiting the study area, such as the Plain-crested Elaenia, Elaenia cristata (Pelzeln, 1868), and Rufous-collared Sparrow, Zonotrichia capensis (Statius Muller, 1776), start to breed as early as the end of August. One possible advantage of the early onset of breeding in $P$. superciliaris could be the increased opportunity to make subsequent nesting attempts in case of nest failure, or possibly the potential for increasing overall fecundity by multiple nesting attempts over an entire breeding season by pairs that are successful in their first effort. Multiple breeding attempts is a common behavior of many tyrant-flycatcher species, such as the Lesser Elaenia, Elaenia chiriquensis Lawrence, 1865, Yellowbellied Elaenia, Elaenia flavogaster (Thunberg, 1822) (SКUTCH 1997); Rusty-margined Flycatcher, Myiozetetes cayanensis (Linnaeus, 1766) (Haverschmidt 1971); Spotted Tody-Flycatcher, Todirostrum maculatum (Desmarest, 1806) (HAVERSCHMIDT 1955); Suiriri Flycatcher, Suiriri suiriri (Vieillot, 1818), and Chapada Flycatcher, S. islerorum Zimmer, Whittaker \& Oren, 2001 (Lopes $\&$ MarINI 2005a). This behavior is also characteristic of many temperate species due to the shorter breeding season, although far less common compared to tropical species (RodRigUes \& CRICK 1997). Another possible advantage to the early onset of breeding in P. superciliaris might be in avoiding the peak period of rainfall (November to March) during the species' breeding period (July to November), which can adversely affect the integrity of the nest structure and directly increase the rate of nestling mortality (D. Hoffmann, pers. comm.).

Nest building conducted exclusively by females and a clutch size of two eggs are characteristics that have been documented for many tyrant-flycathers, particularly in Elaeniinae for species such as $S$. suiriri and S. islerorum (Lopes \& MARINI 2005a), and the E. chiriquensis (Medeiros \& Marini 2007). How- ever, in the Gray-crowned Tyrannulet, Serpophaga griseicapilla Straneck, 2007, both sexes build the nest and the clutch size is two or three eggs (MezQuida \& Marone 2000).

An interval of 48 hours between the laying of each egg and incubation duties performed exclusively by females are considered typical among the species of Tyrannidae (FitzPATRICK 2004). On the other hand, the length of the incubation period appears to be highly variable and it is probably size-dependent, i.e. there might be a correlation between body mass and length of incubation (FiTZPATRick 2004).

Asynchronous breeding, as observed in P. superciliaris, is a common feature of tropical bird species, probably because of the longer breeding season and higher rates of predation (Ricklefs 1969, Moore et al. 2003).

A wide range in the percentage of reproductive success in certain Tyrannidae species, such as $S$. griseicapilla (15.6\%) and Xolmis coronata (Vieillot, 1823) (79.5\%), was documented in Argentina (Mezquida \& Marone 2001). Our study suggests that $P$. superciliaris exhibits an average percentage of reproductive success that is intermediate to these two particular species of Tyrannidae and closer to the lower limit of the range that is characteristic of other Tyrannids (40-80\%) that breed in temperate regions (MARTIN 1993, RICKLEFS 1969).

No large difference was found in the reproductive success of $P$. superciliaris when calculated according to the Mayfield method $(41.8 \%)$ compared to that estimated as a simple percentage (42.3\%). This is probably due to the fact that $95 \%$ of the nests monitored in our study were located while still under construction or at the beginning of the incubation period, avoiding any potential overestimation by simple percentage and reducing the difference in estimates derived from the two different methods (MAYFIELD 1961, 1975). Few studies have been conducted in the Neotropics using the method proposed by Mayfield. In a study focused on E. chiriquensis, R.C.S. Medeiros (Universidade de Brasília, unpub. data) estimated a DSR of 0.948 for eggs and 0.944 for nestlings, with an estimated reproductive success of $21 \%$, which is lower than that observed in $P$. superciliaris. A DSR of 0.956 and 0.962 for eggs and nestlings, respectively, was estimated for Columbina talpacoti (Temminck, 1811) (CINTRA 1988). Both studies found lower overall estimates of DSR and indicated a more similar DSR between nestlings and eggs than we observed in $P$. superciliaris. Alternatively, a larger DSR for eggs, compared to nestlings, has been estimated for S. suiriri and S. islerorum (LOPES \& MARINI 2005b).

The high DSR, which is directly influenced by predation, was the main factor in unsuccessful nesting attempts by $P$. superciliaris, with $75 \%$ of all nests lost in the egg or nestling phases. Along with its similar reproductive success (42.8\%), the rate of predation in $P$. superciliaris was also very close to that observed for species breeding in temperate regions (MARTIN 1993). Even in the Neotropics, the rate of predation may vary according to habitat, time of year and altitude (STUTCHBURY \& Morton 2001), which could explain the great similarity in re- 
productive success and rates of predation that we observed in our study to that documented in temperate regions. However, our estimates are derived from a relatively small sample of nests $(\mathrm{n}=21)$ and represent a single breeding season. Furthermore, a species can exhibit significant variation in reproductive success over multiple years according to environmental variations.

Of those nests lost during the nestling period, 50\% were due to the presence of Philornis sp. larvae. We noted several other species of birds in the study area that were also adversely affected by parasitic larvae, including Embernagra longicauda (Strickland, 1844), Z. capensis and Schistochlamys ruficapillus (Vieillot, 1817) (pers. obs.). Significant rates of nest failure due to the presence of parasites has also been observed elsewhere in S. suiriri, S. islerorum and Sublegatus modestus (Wied, 1831) (Lopes \& Marini 2005b). Thus, parasitism should be considered another important cause of nest failure in the Neotropics.

This study presents important new data concerning the life history of $P$. superciliaris, allowing a better understanding of the reproductive biology of this endemic and near-threatened species. Given that this is the first detailed study of the natural history of this species, we expect that these data will provide a solid starting point for further long-term investigations of its reproductive success and population status in the seriously threatened ecosystem of the Quadrilátero Ferrífero.

\section{ACKNOWLEDGMENTS}

We are grateful to the Instituto Estadual de Florestas de Minas Gerais for permission to work in RM. DH was supported by a MSc grant and MR by a research grant both from Conselho Nacional para o Desenvolvimento Científico e Tecnológico (CNPq). This research was supported by the Neotropical Bird Club, IdeaWild, Fundação O Boticário de Proteção à Natureza, CNPq (473428/2004-0) and Fapemig (PPM CRA APQ-0434-5.03/ 07). We are grateful to all of the volunteers who assisted us in the field and we appreciate the insightful criticism of M.A. Marini, F. Rodrigues, M.F. Vasconcelos, and J.A. Mobley.

\section{LITERATURE CITED}

BirdLIFE. 2004. Threatened Birds of the World 2004. CD-ROM. Cambridge, UK, BirdLife International.

BiRKHEAD, T.R. \& A.P. MøLler. 1992. Sperm competition in birds: evolutionary causes and consequences. London, Academic Press, 282p.

CinTra, R. 1988. Reproductive ecology of the Ruddy GroundDove on the Central Plateau of Brazil. Wilson Bulletin 100 (3): 443-457.

Drummond, G.M.; C.S. Martin; A.B.M. Machado; F.A. Sebaio \& Y. Antonini. 2005. Biodiversidade em Minas Gerais - Um atlas para sua conservação. Belo Horizonte, Fundação Biodiversitas, 222p.

Fitzpatrick, J.W. 2004. Family Tyrannidae (Tyrant-flycatchers), p. 170-462. In: J. Del Hoyo, A. Elliott \& D. Christie (Eds). Handbook of the Birds of the World - Cotingas to Pipits and Wagtails. Barcelona, Spain, Lynx ediciones, 864p.

Haverschmidt, F. 1955. Notes on the life history of Todirostrum maculatum in Surinam. The Auk 72 (4): 325-331.

Haverschmidt, F. 1971. Notes on the life history of the Rustymargined Flycatcher in Surinam. Wilson Bulletin 83 (2): 124-128.

Hensler, G.L. \& J.D. Nichols. 1981. The Mayfield methods of estimating nesting success: A model, estimators and simulation results. Wilson Bulletin 93 (1): 42-53.

Hoffmann, D.; M.F. Vasconcelos; L.E. Lopes \& M. Rodrigues. 2007. Comportamento de forrageamento e dieta de Polystictus superciliaris (Aves, Tyrannidae) no sudeste do Brasil. Iheringia Série Zoologia 97 (3): 296-300. doi: 10.1590/ S0073-47212007000300014.

JaCobi, C.M. \& F.F. Carmo. 2008. The contribution of ironstone outcrops to plant diversity in the Iron Quadrangel, a threatened Brazilian landscape. Ambio 37 (4): 324-326. doi: 10.1579/0044-7447(2008)37[324:TCOIOT]2.0.CO;2.

Jacobi, C.M.; F.F. Carmo; R.C. Vincent \& J.R. Stehmann. 2007. Plant communities on ironstone outcrops: a diverse and endangered Brazilian ecosystem. Biodiversity and Conservation 16 (7): 2785-2200. doi: 10.1007/s10531-0079156-8.

Kempenaers, B. 1993. The use of a breeding synchrony index. Ornis Scandinavica 24 (1): 84.

LoPES, L.E. \& M.Â. MARINI. 2005a. Biologia reprodutiva de Suiriri affinis e $S$. islerorum no Cerrado do Brasil Central. Papéis Avulsos de Zoologia (São Paulo) 45 (12): 127-141. doi: 10.1590/S0031-10492005001200001.

Lopes, L.E. \& M.Â. MarinI. 2005b. Low reproductive success of Campo Suiriri (Suiriri affinis) and Chapada Flycatcher ( $S$. islerorum) in the central Brazilian Cerrado. Bird Conservation International 15 (4): 337-346. doi: 10.1017/S0959270905 000675.

MarinI, M.Â. \& R.D. DurÃEs. 2001. Annual pattern of molt and reproductive activity of passerines in south-central Brazil. Condor 103 (4): 767-775.

Martin, T.E. 1993. Nest predation among vegetation layers and habitat types: Revising the dogmas. American Naturalist 141 (6): 897-913.

Mason, P. 1985. The nesting biology of some passerines of Buenos Aires, Argentina. Ornithological Monographs 36 (1): 954-972.

MaYfield, H. 1961. Nesting success calculated from exposure. Wilson Bulletin 73 (3): 255-261.

Mayfield, H. 1975. Suggestions for calculating nest success. Wilson Bulletin 87 (4): 456-466.

Medeiros, R.C.S. \& M.Â. Marini. 2007. Biologia reprodutiva de Elaenia chiriquensis (Lawrence) (Aves, Tyrannidae) em Cerrado do Brasil Central. Revista Brasileira de Zoologia 24 (1): 12-20. 
Mezquida, E.T. \& L. Marone. 2000. Breeding biology of Graycrowned Tyrannulet in the Monte desert, Argentina. Condor 102 (1): 205-210.

Mezquida, E.T. \& L. Marone. 2001. Factors affecting nesting success of a bird assembly in the central Monte Desert, Argentina. Journal of Avian Biology 32 (4): 287-296.

Mittermeier, R.A.; P.R. Gil; M. Hoffmann; J. Pilgrim; J. Brooks; C.G. Mittermeier; J. Lamourux \& G.A.B. Fonseca. 2004. Hotspots revisited: earth's biologically richest and most endangered terrestrial ecoregions. Mexico City, México, Cemex, 392p.

Moore, O.R.; B.J.M. Stutchbury \& J.S. Quinn. 1999. Extrapair mating system of an asynchronously breeding tropical songbird: the Mangrove Swallow. The Auk 116 (4): 1039-1046.

NimER, E. \& A.M.P.M. BRAndão. 1989. Balanço hídrico e clima de região dos cerrados. Rio de Janeiro, Instituto Brasileiro de Geografia e Estatística, 166p.

RickLEFs, R.E. 1969. An analysis of nesting mortality in birds. Smithsonian Contributions to Zoology 9 (1): 1-48.

Robinson, W.D.; T.R. Robinson; S.K. Robinson \& J.D. Brawn. 2000. Nesting success of understory forest birds in central Panama. Journal of Avian Biology 31 (2): 151-164.

RodRIGUES, M. 1996. Parental care and polygyny in the Chiffchaff Phylloscopus collybita. Behaviour 133 (13): 1077-7094.

Rodrigues, M. \& H.Q.P. CRICK. 1997. The breeding biology of the Chiffchaff Phylloscopus collybita in Britain: a comparison of an intensive study with records of the BTO Nest Record Scheme. Bird Study 44 (3): 374-383.
Simon, J.E. \& S. Pacheco. 2005. On the standardization of nest descriptions of neotropical birds. Revista Brasileira de Ornitologia 13 (2): 7-18.

Sкuтch, A.F. 1997. Life of the Flycatcher. Norman, University of Oklahoma Press, 162p.

Stattersfield, A.J.; M.J. Crosby; A.J. Long \& D. Wege. 1998. Endemic birds areas of the world: Priorities for biodiversity conservation. Cambridge, BirdLife International, 860p.

Stutchbury, B.J.M. \& E.S. Morton. 2001. Behavioral ecology of tropical birds. San Diego USA, Academic Press, 161p.

Teixeira, W.A. \& J.P. Lemos Filho. 2002. Fatores edáficos e a colonização de espécies lenhosas em uma cava de mineração de ferro em Itabirito, Minas Gerais. Revista Árvore 26 (1): 25 33.

VASCONCELOS, M.F. 1999. Natural history notes and conservation of two species endemic to the Espinhaço Range, Brazil: Hyacinth Visorbearer Augastes scutatus and Grey-backed Tachuri Polystictus superciliaris. Cotinga 11 (1): 75-78.

VAsconcelos, M.F. \& J.A. Lombardi. 1996. Primeira descrição do ninho e do ovo de Polystictus superciliaris (Passeriformes: Tyrannidae) ocorrente na Serra do Curral, Minas Gerais. Ararajuba 4 (2): 114-116.

Vasconcelos, M.F.; M. Maldonado-Coelho \& D.R.C. Buzzetti. 2003. Range extension for the Gray-backed Tachuri (Polystictus superciliaris) and the Pale-throated Serra-Finch (Embernagra longicauda) with the revision on their geographic distribution. Ornitología Neotropical 14 (4): 477-489.

Submitted: 21.III.2010; Accepted: 07.IV.2010.

Editorial responsibility: Walter A.P. Boeger

ZOOLOGIA 28 (3): 305-311, June, 2011 